\title{
Zs Research S Suare \\ Docking and in silico toxicity assessment of Arthrospira compounds as potential antiviral agents against SARS-CoV-2
}

\author{
Lena PETIT \\ Algama https://orcid.org/0000-0003-1315-5821 \\ Lea VERNES \\ Algama https://orcid.org/0000-0002-8115-2609 \\ Jean-Paul CADORET ( $\nabla$ jeanpaul.cadoret@algamafoods.com ) \\ Algama https://orcid.org/0000-0001-7542-5474
}

\section{Research Article}

Keywords: Covid-19, SARS-CoV-2, Arthrospira, Antiviral, Docking.

Posted Date: July 10th, 2020

DOI: https://doi.org/10.21203/rs.3.rs-40890/v1

License: () (1) This work is licensed under a Creative Commons Attribution 4.0 International License. Read Full License

Version of Record: A version of this preprint was published at Journal of Applied Phycology on March 20th, 2021. See the published version at https://doi.org/10.1007/s10811-021-02372-9. 


\section{Abstract}

A course is currently being launched as a result of the international health situation. This race aims to find, by various means, weapons to counter the Covid-19 pandemic now widespread on all continents. The aquatic world and in particular that of photosynthetic organisms is regularly highlighted but paradoxically little exploited in view of the tremendous possibilities it offers. Computational tools allow not only to clear the existence and activity of many molecules, but also to model their relationships with receptors identified in potential hosts. On a routine basis, our laboratory carries out a research activity on functionalities of molecules derived from algae, using in silico tools. We have implemented our skills, in algae biology and in modeling, as tests in order to identify molecules expressed by the genus Arthrospira showing an antiviral potential and more particularly anti SARS-CoV-2. Using Autodock Vina, we were able to identify 3 molecules: phycocyanobilin, phycoerythrobilin and folic acid. These 3 compounds showed binding energies able to compete with the SARS-CoV-2/ACE2 complex. Toxicity prediction as well as current regulations support their use as potential candidates for the fight against Covid- 19 .

\section{Introduction}

Covid-19 is probably the most written, published acronym in this year 2020. This is for objective and obvious reasons. Covid-19 is the pandemic caused by SARS-CoV-2 (Severe acute respiratory syndrome coronavirus 2) and it has overturned the entire planet as few pandemics have done, and this, in a modern era which has deployed modern and high-level medicine. Research on these pandemics takes multiple paths whether on technical, chemical or biological levels. We then attack the biology of viruses or the defense mechanisms of their hosts. Different methods can be used for antiviral research to act against SARSCoV-2. We can first target structural proteins in view to inhibit virus entry in human host cells or looking for functional internal viral protein inhibitors to block for example its replication. A third method would be to target human receptor for virus entry prevention. In view to limit the impact on the human metabolism of such antivirals, we rather focused on the first critical step for the virus, its recognition by the host cell, mediated via specific structural proteins, spike proteins. As a food tech company, Algama produces innovative food ingredients made with microalgae. As a part of our daily research, we developed a tool enabling to select the most relevant molecules from microalgae for different food applications according to various criteria (bioavailability, safety, drug interaction...). In the context of the Covid-19 health crisis and to contribute to the collective effort, we tested our methodology towards antiviral compound identification from microalgae. Based on a literature framework about antivirals from Arthrospira $s p$, the aim of this study was to identify the most relevant SARS-CoV-2 antiviral molecules thanks to docking, and to conduct an in silico toxicity assessment of the most efficient antiviral compounds. The first part of this work focuses on the description of the virus and presents a state of the art of Arthrospira use as an antiviral agent. The second part of the article deals with the evaluation of the anti-SARS-CoV-2 activity by docking Arthrospira compounds. Finally, an in silico study of the selected molecules toxicity will be proposed.

\section{Sars-cov-2}

SARS-CoV-2 belongs to the coronavirus family, composed of enveloped virus with positive strain of RNA. Its genome is contained in a capsid formed by nucleocapsid proteins, itself included in an envelope. Three structural proteins are characteristic of coronavirus: membrane protein, envelope protein, and spike protein (S), a glycoprotein responsible for virus host cell attachment (Li 2016). Coronavirus took their name from "corona" (crown in Latin), formed by S protein protuberances on their surface.

The spike (S) glycoprotein ectodomain consists in a trimeric structure. Each monomer is composed of two subunits: S1, involved in the host cell receptor recognition and S2, responsible for the membrane-fusion mechanism. S1 subunit contains two major domains, N-terminal domain (S1-NTD) and C-terminal domain (S1-CTD) (Li 2016) (Fig. 1). The latter constitutes the receptor binding domain (RBD) and is composed of two subdomains: a core structure and a receptor-binding motif (RBM) (Li et al. 2005). 
Zhou et al. (2020) recently determined the ability of SARS-CoV-2 to use human angiotensin-converting enzyme 2 (ACE2) as receptor to engage virus attachment to the host cell via its RBD, as for SARS-CoV. However, they excluded binding with other coronavirus receptors such as APN and DPP4 (Li 2016). Angiotensin-converting enzyme 2 (ACE2) identification as main receptor of SARS-CoV-2 in human has been confirmed shortly after by two other research teams (Ou et al. 2020; Hoffmann et al. 2020).

ACE2 is a metallocarboxypeptidase involved in arterial pressure system via cleavage of angiotensin peptides (Donoghue et al. 2000). It has been shown to be expressed in lung alveolar epithelial cells, in enterocytes of small intestine and in vascular endothelium (Hamming et al. 2004), explaining the location of Covid-19 pathologic symptoms. ACE2 binding site to SARS-CoV2 was found to be within its extracellular peptidase domain (Yan et al. 2020).

Once coronavirus RBD is linked to ACE2 peptidase domain, the prefusion S protein becomes unstable and is submitted to a first proteolytic activation via a host cell protease, between S1 and S2 subunits (Walls et al. 2017). In addition to S1/S2 cleavage, a second site, critical for viral fusion, has been determined within the S2 domain, on the S2' site (Belouzard et al. 2009). This second proteolysis results in the shedding of S1 subunit and exposes an internal fusion peptide. This one is essential for fusion of the virus and host membrane via S2 subunit, leading to the viral genome release in ACE2. This peptide is highly conserved among coronavirus (Madu et al. 2009) and composed of serine residues 798 to phenylalanine 815 in SARSCoV.

TMPRSS2 was identified in lung cells as the main human protease used by SARS-CoV-2 for S protein modification (Hoffmann et al. 2020). TMPRSS2 belongs to the Type II transmembrane serine proteases (TTSPs) which have been involved in the spread of various respiratory viruses (Choi et al. 2009). Expressed in airway epithelial cells (Böttcher et al. 2006), Shulla et al. (2011) further pointed the colocalization of TMPRSS2 and ACE2 during an immunoprecipitation assay. In this context, SARSCoV-2 using the same receptor (ACE2) and host cell protease (TMPRSS2) than SARS-CoV, this colocalization appears to sorely facilitate its entry and spreading in human host cells.

Gui et al. (2017) determined different conformational prefusion states of SARS-CoV S protein. Each Spike RBD on the S1 subunit of SARS-CoV can be found in two conformational states, one "up" and one "down". In down position, SARS-CoV RBD was reported as inaccessible for ACE2 recognition, due to steric clashes. On the contrary, when a trimer is in "up" position, RBD is then exposed, allowing its binding with host cell ACE2 (Gui et al. 2017; Yuan et al. 2017).

At this day, two conformational states of the S protein have been found in SARS-CoV-2 (Wrapp et al. 2020; Walls et al. 2020). As for SARS-CoV, one presents all RBD in down state (not completely closed according the Cryo-EM assays) and the second shows one of the three RBD exposed in an open state. Like for its predecessor, SARS-CoV-2 RBD binding with ACE2 seems to be impossible when the Spike trimer is entirely in down conformation. On the contrary, with one RBD in up position, no steric clash with S protein was detected, suggesting that an open state is required for Spike protein binding with its receptor (Yan et al. 2020).

As crystal structure of RBD has been defined with a better resolution than the open state of the SARS-CoV-2 Spike ectodomain structure, and as no complete complex of Spike protein with ACE2 was available, RBD section of the S protein was chosen for this work. This further ensured to use a valid conformational state of the RBD.

Key binding residues involved in the Spike/ACE2 link were elucidated in several papers. Final consensus sequence for binding site on ACE2 was established from residues highlighted by the several teams (Yan et al. 2020; Lan et al. 2020; Shang et al. 2020; Wang et al. 2020): S19, Q24, F28, D30, K31, H34, E35, D38, Y41, Q42, L79, M82, Y83, K353, D355, R357. Regarding Spike glycoprotein, consensus for ACE2 binding residues has been established has followed: K417, G446, Y449, Y453, L455, A475, F486,N487, Y489, Q493, G496, Q498, T500, N501, G502 (Yan et al. 2020; Walls et al. 2020; Lan et al. 2020; Shang et al. 2020; Wang et al. 2020) (Table 1).

\section{Algae and antiviral activities}


The term "algae" actually includes a wide variety of organisms with a complex evolutionary history. These organisms have features in common such as the ability to do photosynthesis and being predominantly aquatic. We can distinguish two main categories of algae: macroalgae, multicellular eukaryotes and microalgae, in the largest sense of the word, including unicellular eukaryotes and prokaryotes. Most macroalgae are found in seawater and are called "algae", but some can also be found in freshwater (e.g.: Oedogonium, Cladophora and Spirogyra). Microalgae are found in both environments, but the most consumed species (Arthrospira, Klamath and Chlorella) generally grow in freshwater.

These aquatic plants are known to be rich in proteins and lipids, but also offer a wide range of immunostimulatory, antioxidant and antiviral properties. Numerous publications have reviewed the generic properties of algae in these areas (Mimouni et al. 2012). For example, the immune response in the cytokines which is tested by Talukdar et al. (2020) with astaxanthin. Griffithsin, a lectin isolated from red algae Griffithsia has shown activity on protein S of MERS-CoV (Middle East Respiratory Syndrome Coronavirus)(Millet et al. 2016). As for microalgae, the very numerous studies have been compiled by de la Jara et al. (2018) and Perumal and Sundararaj (2020).

\section{Antiviral compounds from Arthrospira state of the art (tables)}

Arthrospira gender refers to prokaryotic filamentous cyanobacteria. The best-known species, Arthrospira platensis and Arthrospira maxima, are mostly used as food supplement due to their nutritional properties: high protein content, vitamins, minerals... Moreover, Arthrospira also contains various metabolites with beneficial health properties such as polyphenols, carotenoids, sterols. Due to drug-resistant virus strains emergence, and because of adverse effects caused by usual synthetic antiviral treatments, increasingly researchers are looking into more natural approaches. This explains a growing interest in antivirals from natural source, in algae in general and in Arthrospira for example in particular. Hence, in vitro and in vivo studies have been conducted to evaluate Arthrospira compounds as antiviral against various viruses such as Influenza, Herpes simplex virus (HSV), Hepatitis C (HCV)...as presented in Tables 2 and 3.

Data from scientific literature were critically reviewed in order to highlight results of the most rigorous studies: presence of controls, replicates, measurement of toxicity, and inhibition efficacy. The following information were collected and analyzed: $\mathrm{CC}_{50}$, cytotoxic concentration of the compounds decreasing in vitro cell viability to $50 \%$; $\mathrm{EC}_{50}$, effective concentration needed to inhibit $50 \%$ of virus; and therapeutic index (TI or SI), referring to the ratio $\mathrm{CC}_{50} / \mathrm{EC}_{50}$. A high therapeutic index $(\mathrm{TI})$, or selectivity index $(\mathrm{SI})$, is preferable for a drug to have a favorable safety and efficacy profile.

Radonic et al. (2010) evaluate the effect of sulphur-containing exopolysaccharides from A. platensis (TKV3). According to their study, anionic polysaccharides from Arthrospira showed antiviral activity against enveloped virus such as VACV (EC ${ }_{50}$ (TK V3) $=0.78 \mu \mathrm{g} \cdot \mathrm{mL}^{-1}$ ) via interactions with viral membrane glycoproteins and thus inhibition of virus binding to host cells. In the work of Chen et al. (2016), Arthrospira extract was capable of inhibiting in vitro influenza viral replication and plaque formation (Table 2), by targeting hemagglutinin, an influenza virus surface glycoprotein.

Abdo et al. (2012), El-Baz et al. (2013), Deyab et al. (2020), and Hetta et al. (2014), focused on A. platensis antiviral effect on adenovirus and Coxsackievirus (CV). Most of them evaluate Arthrospira methanol extract activity on Hep 2 cell in vitro model. In all cases, Arthrospira appears as a good antiviral agent: reducing virus titer from $50 \%$, preventing virus attach to host cell receptor when used as pre-treatment with $\mathrm{TI}(\mathrm{CVB} 3)=30$ and $\mathrm{TI}(\mathrm{RV})=45$ (Deyab et al. 2020). Efficiency of methanolic extract is attributed to the presence of polar compounds binding to viral capsid. Moreover, El-Baz et al. (2013) found that Arthrospira ethanolic extract was active against non-enveloped RNA and DNA viruses. However, authors did not compare Arthrospira effect with a control drug since there is no available drug against enteric virus according to them.

Elsewhere, Rechter et al. (2006) compared spirulan-like substance to ganciclovir (GCV), a reference drug used as antiherpesvirus. According to their in vitro experiments, preincubation of substances enhances antiviral activity via virus entry and replication inhibition: $\mathrm{EC}_{50}(\mathrm{TK}-\mathrm{V} 3 \mathrm{a})=1.4 \pm 0.3 \mu \mathrm{g} \cdot \mathrm{mL}^{-1}$, close to drug reference $\mathrm{EC}_{50}=0.7 \pm 0.1 \mu \mathrm{g} \cdot \mathrm{mL}^{-1}$ in post incubation

(Table 2). 
Due to the emergence of drug-resistant Herpes simplex strains, several studies have focused on the search for alternatives to synthetical acyclovir in the prevention and treatment of Herpes Simplex Virus (HSV) 1 and 2. For instance, hot water extract of A. maxima provided $\mathrm{EC}_{50}$ of $0.069 \mathrm{mg} \cdot \mathrm{mL}^{-1}$ against HSV-2. The Authors then attributed this antiviral activity to high polar compounds (Hernández-Corona et al. 2002). In a second study, phosphate buffer extract of $A$. fusiformis showed a viral infection inhibition almost as high as acyclovir (85\% against $99 \%$ ) during the intracellular replication period (Schnitzler et al. 2013). In the same way, Chirasuwan et al. (2009) evaluated in vitro A. platensis extract as potential HSV antiviral agent to propose an alternative to the synthetic anti-herpes drug acyclovir. Sulfoquinovosyl diacylglycerol (SQDG) was responsible for antiviral activity of $A$. platensis lipid fraction $\left(E_{50}=6.8 \mu \mathrm{g} \cdot \mathrm{mL}^{-1}\right)$ with an effect comparable to the reference drug $\left(E_{50}=1.5\right.$ $\left.\mu \mathrm{g} \cdot \mathrm{mL}^{-1}\right)$, without toxicity for cells. This activity is due to DNA polymerase inhibition thanks to SQDG interaction with different regions of the enzyme. Furthermore, Lee et al (2007) highlighted antiviral potency of spirulan molecules from A. platensis. Best in vitro results were obtained when compounds were added to the medium during HSV-1 and 2 infections. Na-Sp then showed the highest selectivity indexes of 13,000 and 17,000 , with very low $\mathrm{ECs}_{50}\left(0.63\right.$ and $\left.0.41 \mu \mathrm{g} \cdot \mathrm{mL}^{-1}\right)$. Otherwise, Shalaby et al (2010) attributed the observed Hepatitis-A (RNA virus) and HSV-1 antiviral effect of aqueous and phosphate buffer extracts to the sulphated polysaccharides and tannins. According to them, these compounds may interfere at different viral stage such as attachment and penetration of the virus.

In the case of Kok et al. (2011) study, different extracts from microalgae were compared to conventional drugs (acyclovir \& foscarnet) for their antiviral capacity against Epstein-Barr Virus (EBV). Methanol extract from A. platensis reduced the cell-free EBV DNA load in B95-8 cells with an $\mathrm{EC}_{50}$ of $0.021 \mu \mathrm{g} \cdot \mathrm{mL}^{-1}$ with an $\mathrm{CC}_{50}$ of $166 \mu \mathrm{g} \cdot \mathrm{mL}^{-1}$ (TI=7905) (Kok et al. 2011).

Peptides were also evaluated as antiviral agent. Indeed, Jang and Park (2016) found that SM peptide, isolated from $A$. maxima, displayed in vitro antiviral activity since it inhibited reverse transcriptase activity in HIV-1 infected cell by $90 \%$ compared to the no-peptide assay. Moreover, $0.75 \mathrm{mg}_{\mathrm{mL}}{ }^{-1}$ of SM peptide inhibited HIV-1 p24 antibody production by more than 95\%, without toxicity for the cells. Similarly, Ayehunie et al. (1998) evaluate HIV antiviral activity of Arthrospira. According to their results, both polysaccharide fraction and the fraction depleted in polysaccharide and tannin of $A$. platensis inhibited in vitro HIV-1 replication. Preincubation of polysaccharide fraction extract with cells showed better results due to polysaccharides binding to CD4 receptors, thus preventing virus attachment to the host cell through its gp120 envelope glycoprotein.

According to in vitro studies presented above, Arthrospira has antiviral properties against different types of viruses: Herpes simplex, hepatitis, vaccinia, coxsakievirus.... It has no, or very little, cytotoxicity to cells, and low doses $\left(\mathrm{EC}_{50}\right)$ are sufficient to induce an effect $\left(1-10 \mu \mathrm{g} \cdot \mathrm{mL}^{-1}\right)$ with high therapeutic indices. It seems that Arthrospira compounds act during the early stages of viral infection. According to the main hypotheses evoked, compounds of polar nature and mainly sulphated polysaccharides and peptides are responsible for interactions with viral envelope glycoproteins, thus preventing binding to the host cell. Calcium spirulan, a sulfated polysaccharide from Arthrospira, is the most cited compounds with antiviral activity against various enveloped virus. The sulfate groups as well as the carboxyl groups of polysaccharides, such as Ca-Sp isolated from the extract, have negative charges which can react with the basic amino acids of viral proteins and block the interaction with cellular receptors.

In order to confirm in vitro results, a second state of the art was carried out focusing on human clinical studies involving the use of Arthrospira as an antiviral agent (Table 3).

Most of the in vivo studies focused on Arthrospira supplementation effect on HIV-infected patients. Tpday, there is no treatment capable of eradicating AIDS. HIV-infected patients still carry the virus and they can spread it to others. So far, there are five major classes of anti-HIV drugs that targets distinct steps in the virus life cycle: reverse transcriptase inhibitors, protease inhibitors, fusion inhibitors, integrase inhibitors, and multidrug combinations (Jang and Park 2016). To improve therapeutic potential of existing medicines, research on Arthrospira-based novel treatment have been conducted. 
In this context, Winter et al. (2014) conducted an in vivo study on 73 HIV-infected women to evaluate Arthrospira supplementation effect. The study was a three-month pilot, randomized, double-blind and placebo-controlled intervention. No significant clinical effect of Arthrospira supplementation was observed regarding viral load and CD4 cells; nevertheless, Arthrospira supplementation showed a positive effect on weight stabilization and protection against opportunistic infections. Similarly, Teas and Irimeh (2012) found that Arthrospira strengthen immune system of affected patients. Unfortunately, sample size of selected patients for this study was too small (11) to conclude that there were significant effects of Arthrospira supplementation. Ngo-Matip et al. (2015) conducted a single-blind, randomized, multicenter study on 320 HIV-1 ARV-naïve participants for 12 months to analyze Arthrospira supplementation effect compared to local diet, both with standard HIV therapy. This work confirmed previous results, showing that Arthrospira supplementation intake positively and significantly stimulated the immune system and inhibited virus replication of HIV-infected subjects. As in the previous cases, Arthrospira contributed to the proper functioning of immune system and thus helped to limit the appearance of opportunistic diseases. Similar results were also obtained by Azabji-Kenkack et al. (2011), indicating that Arthrospira supplementation helps HIVinfected and malnourished adults to improve their immune defenses (Azabji-Kenfack et al. 2011). For this experiment, authors compared effects of Arthrospira and soya beans supplementation. Like other studies, Arthrospira supplement improved general state of health by promoting weight gain of malnourished adults infected with HIV. Regarding the baseline and the results obtained with soya beans, Arthrospira consumption reduced significatively viral load and increased CD4 count (AzabjiKenfack et al. 2011).

Two in vivo studies listed in table 2 focused on Arthrospira effect in the case of hepatitis C-infection (HCV). In the work of Gomaa et al. (2017), Arthrospira was added to usual thalassemic drug for 6 months to evaluate the effect on thalassemic HCV-infected children. As patients are suffering from 2 different pathologies, it was difficult to affirm that Arthrospira was responsible for health improvement. However, authors conclude that Arthrospira stimulated immune system of thalassemic children infected with HCV since CD4 and CD8 number was increased after 6 months of Arthrospira intake. They also state that phycocyanin from Arthrospira stimulated hematopoiesis, by inducing erythropoietin hormone (EPO) release, thus helping thalassemia children. Moreover, Yakoot and Salem (2012) conducted an in vivo study comparing the effect of Arthrospira and Silymarin against hepatitis $\mathrm{C}$. For this study, sixty-six patients with chronic hepatitis $\mathrm{C}$ virus infection had been randomized, double-blind, and treated with Arthrospira or Silymarin for a period of six-months treatment. According to their results, Arthrospira helped to improve general well-being of patients and has led to a loss or reduction of detectable hepatitis $C$ virus RNA for 6 patients. Compared to the second group treated with Silymarin, these results were no significant (0.12) (Table 2). Nevertheless, this study did not include a placebo control since Silymarin possess itself some benefits in the treatment of viral hepatitis. Thus, it does not allow to conclude on these results.

According to these in vivo studies, it appears that Arthrospira improves the general health of AIDS and HCV-infected patients by contributing to restore their body's defense mechanism against infectious immune system disorder, thus limiting opportunistic diseases. According to these results, Arthrospira may significantly affect virus progression according to some studies. However, most studies conducted in vivo on human patients have evaluated the effect of daily Arthrospira supplementation in addition to the usual antiviral treatment. These studies were mostly randomized and double-blind, but the study duration was often short with a small number of patients and did not always present a placebo control. It could be interesting to evaluate the effect of Arthrospira alone, without other antiviral treatment, in a rigorous long-term study to confirm its antiviral potential.

According to this literature review, Arthrospira acts as antiviral against various type of viruses. Indeed, significant antiviral effects were observed in vitro, and in vivo studies confirmed that Arthrospira is well-tolerated by patients and even improved their general state of health by increasing immune response. Arthrospira can thus be administered in addition to current gold standard therapy in order to improve its effects, or it can also be considered as an interesting alternative to certain drugs with serious adverse effects. Many compounds such as sulfated polysaccharides (Calcium-spirulan), fatty acids (Hetta et al. 2014) and proteins (C-phycocyanin, cyanovirin-N, microvirin) have been identified as responsible for this antiviral activity. Indeed, these compounds can bind to glycoprotein virus envelope, and thus hinder virus attachment to its host cell. Nevertheless, according to Ayehunie et al. (1998), it appears that other compounds than polysaccharides and tannins, present in the 
aqueous extract of Arthrospira, may also have an antiviral activity. To go further, it might therefore be interesting to evaluate the antiviral potential of other Arthrospira metabolites.

Few studies have been identified in the literature as dealing with the antiviral potential of microalgae compounds against SARS-Cov-2. For instance, astaxanthin as well as linolenic acid (C18:00) have been mentioned as potential candidates for the treatment or the prevention of Covid-19. (DOI: 10.31219/osf.io/yahd4; URL:

https://preprints.aijr.org/index.php/ap/preprint/view/36). The use of docking in order to test Arthrospira as a candidate against SARS-CoV-2 is original. A pre-published work publicly available, highlighted Arthrospira potential on two viral proteins. However, it was based on SARS-CoV-1 database, and it is pending for publication (DOI: 10.26434/chemrxiv.12051927) These are pre-published studies and the confirmation of the robustness will be given upon the final peer reviewed publications. Moreover, very few authors have taken an interest in the specific case of Arthrospira, and most of the articles present a literature survey without in silico, in vitro or in vivo evaluation.

In order to propose new antiviral leads from Arthrospira, this study evaluates in silico the antiviral potential of Arthrospira metabolites using an updated database specific to SARS-coV-2 thanks to docking tools. Molecular docking is a computational method which simulates different orientations of a protein and a ligand to predict the most stable complex, with a minimal free energy. Based on algorithms, best binding-conformations, as well as binding affinity are defined.

In order to contribute to the collective effort to find a solution to the current global Covid-19 crisis and to further explore the antiviral potential of Arthrospira, this article investigates antiviral activity of Arthrospira molecules from Algama internal database. This database is composed of 51 high value molecules from Arthrospira genus.

\section{Materials And Methods}

\section{Protein-protein docking}

Two crystal structures of the receptor-binding domain (RBD) of SARS-CoV-2 Spike protein bound to the cell receptor ACE2 have been determined (Lan et al. 2020; Wang et al. 2020) and deposed on the Protein Data Bank under the respective codes 6M0J and 6LZG. Both structures were used as experimental controls by submitted them to Prodigy tool with a temperature set to $25^{\circ} \mathrm{C}$ (Vangone and Bonvin 2015; Xue et al. 2016) for protein-protein binding affinity prediction.

\section{Protein-ligand docking}

All the docking assays were executed with the firstly deposed crystal structure of the complex, corresponding to the 6LZG identifier (Wang et al. 2020). RBD part was extracted from this crystal complex using Discovery Studio Visualizer, thus expecting having the most relevant conformation of the RBD in the Spike/ACE2 complex (Forli et al. 2016). Receptor structure was then prepared, heteroatoms (included water) were deleted, all the hydrogens were added, and the file was saved as PDB file.

Ligands were divided into two categories: small molecules (mainly secondary metabolites) and peptides. Small molecule structures were obtained from Pubchem and downloaded as SDF format. Peptide sequences were taken from literature and converted in SMILES format via NIH Cactus translator, and then in SDF format in Open Babel (O'Boyle et al. 2011). All the 51 ligands from Algama database were energy minimized before being finally converted in PDBQT format on PyRx (Dallakyan and Olson 2015).

Docking was executed with Autodock Vina (Trott and Olson 2010) on the PyRx software (Dallakyan and Olson 2015). The grid box was manually adjusted around active residues identified above, with following coordinates: X:-37.348; Y: 29.6843; Z:

3.1984 and dimensions : $X: 29.0036 \AA$; Y: $56.1876 \AA ̊$; Z: $24.9881 \AA$. Exhaustiveness was set on 10, equivalent to the short mode, since no statistically significant difference in accuracy was detected using the short, medium or long mode of Autodock Vina (Nguyen et al. 2020). 
Binding affinity result files were exported as CSV for analysis and docked structures were visualized in Discovery Studio Visualizer in view to obtain a complete structure of each complex. Ligand interactions were determined with this same tool and analyzed to target better candidates for SARS-CoV-2 RDB binding. Those with both a relevant binding affinity with the receptor, low RMSD values, and favorable interactions with residues involved in the RBD/ACE2 link were selected for deeper analysis.

\section{In silico toxicity assessment}

Toxicity of each selected molecules was assessed via the AdmetSAR 2 prediction tool (Yang et al. 2019), using canonical smiles from Pubchem for compound identification.

Acute oral toxicity was determined through toxicity class. Carcinogenicity, mutagenicity, and hepatotoxicity were also predicted. In view to avoid interaction with other potential treatment, it was needed to study the main cytochrome as well as Pglycoprotein to avoid drug interactions.

\section{Results}

\section{Docking}

Both RBD/ACE2 complexes docked as control provided similar binding affinity around $-12 \mathrm{kcal}^{\mathrm{mol}}{ }^{-1}$. As comparison, entire Spike glycoprotein complexed with ACE2 has been submitted to the same analysis by another team, still using Prodigy, after docking between ACE2 (PDB code: 1R42) and Spike protein isolated from the PDB structure 6ACK (Ortega et al. 2020). Binding energy was then established at $-15.7 \mathrm{kcal}_{\mathrm{mol}}{ }^{-1}$, a result quite lower, probably explained by the low resolution of the Spike portion $(4.50 \AA)$.

After docking the 51 molecules from Algama internal database with Spike RBD in Autodock Vina, the first three modes were selected for each compound, corresponding to the best three binding affinities (Table 6 Supplemental data). Only values less

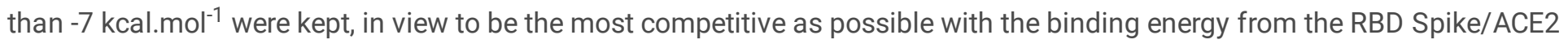
complex. Out of the 153 conformations presented here, 23 fulfilled this criterion. To ensure stability of selected conformations, we selected those with both their RMSD/ub and RMSD/lb lower than $2 \AA$ (Trott and Olson 2010). 13 conformations were then obtained, corresponding to 11 compounds (Table 4): catechin, epicatechin, dieckol, apigenin, $\beta$-carotene, rutin, astaxanthin, rosmarinic acid, phycobilin, phycoerythrobilin and folic acid. After comparison of number and localization of $\mathrm{H}$-bonds, unfavorable interactions, total and nature of interactions, and number of key residues involved in those interactions, 3 compounds were finally identified: phycobilin, phycoerythrobilin and folic acid. Despite its high binding affinity, dieckol was not selected because it only had one $\mathrm{H}$-bond and included two unfavorable interactions which will tend to break the link with RBD.

\section{Phycocyanobilin}

Phycocyanobilin / Spike RBD complex is composed of 5 Van der Waals interactions, with residues ARG403, TYR453, LEU492, GLN493 and ASN501 (Fig. 2). Five $\pi$-Alkyl bonds are involved between phycocyanobilin and Spike RBD, distributed between TYR449, TYR495, PHE497 and TYR505, consolidated by a H-bond on TYR449. Three other H-bonds engage SER494, GLY496 and GLN498. Finally, GLY496 is also linked to phycocyanobilin via a $\pi$-Donor hydrogen bond. Binding affinity for this compound reaches $-7.2 \mathrm{kcal}^{\mathrm{mol}}{ }^{-1}$ and is not impeded by unfavorable strength, highlighting a good potential for antiviral activity.

\section{Phycoerythrobilin}

Phycoerythrobilin binds to Spike RBD via 9 Van der Waals interactions, with following residues: GLU406, GLN409, LEU455, GLN493, TYR495, PHE497, GLN498, ASN501, TYR505. Additionally, 3 alkyl and $\pi$-alkyl interactions engage LYS417, TYR449 and TYR453. ARG403 is involved in two different kinds of bonds: one r-cation and one carbon-hydrogen bond. A second carbon-hydrogen bond links SER494 to Spike RBD, as well as one H-bond. The two last H-bonds are located on the GLY496 residue (Fig. 3). Thus, with four key binding amino acids involved in different interactions including two $\mathrm{H}$-bonds on them, 
phycoerythrobilin shows an interesting binding affinity of $-7.3 \mathrm{kcal}^{\mathrm{mol}}{ }^{-1}$. These results provide us good arguments for deeper research on a phycoerythrobilin based antiviral.

\section{Folic acid}

Folic acid presents 4 van der Waals interactions with RBD Spike, engaging LYS417, SER494, PHE497 and TYR505 residues. 3 $\pi$-cation and one $\pi$-anion interactions are detected on the AR403 and the ASP405. One $\pi-\pi$ stacked interaction engages the aromatic group of folic acid with TYR453. Three carbon hydrogen bonds are highlighted on two residues, GLU406 and TYR495. Despite an unfavorable donor-donor interaction on the arginine 408, 6 conventional hydrogen bonds are predicted on ASP405, GLU406, GLN409, GLY496, GLN498 and ASN501 (Fig. 4). With a binding energy of $-7.4 \mathrm{kcal}^{\text {.mol }}{ }^{-1}$ and 6 hydrogen bonds of which 3 are engaged with residues directly involved in Spike/ACE2 link (GLY496, GLN498 and ASN501), folic acid is suggested as a great mid-competitive inhibitor to block the virus attachment and entry via ACE2 human receptor.

Both three selected compounds presented competitive binding energies regarding the control complex. This later reached -12.4 $\mathrm{kcal} . \mathrm{mol}^{-1}$ whereas phycocyanobilin, phycoerythrobilin and folic acid presented binding energies of respectively $-7.2,-7.3$ and $-7.4 \mathrm{kcal}^{\mathrm{mol}}{ }^{-1}$. These values, added to favorable solid interactions, suggest these three molecules could constitute midcompetitive inhibitors for the Spike / ACE2 link. Such inhibition could limit the hanging of SARS-CoV-2 on the human host receptor ACE2 and thus contribute efficiently to the fight against Covid-19.

\section{Toxicity assessment}

After toxicity prediction with AdmetSAR 2 tool, each selected molecule was analyzed regarding specific toxicity criteria (Table 5). None of the tested compounds present neither mutagenicity nor carcinogenicity. All of them possess acute oral toxicities included in the third class of toxicity. This later corresponds to $L_{50}$ comprised between 500 and 5000 mg.kg-1 a low toxicity level, equivalent to the $4^{\text {th }}$ class of toxicity in the Hodge and Sterner class. Phycoerythrobilin and folic acid showed no potential inhibition of following cytochromes: CYP1A2, CYP2C19, CYP2C9, CYP2D6 and CYP3A4. Regarding phycocyanobilin, two inhibitions against CYP1A2 and CYP2C9 were detected with a probability of 0.52 . As this value is below 0.70 , it was considered as not enough statistically significant. Nevertheless, in vitro and in vivo studies remain essential to warrant these results. The three compounds respond positively to the hepatotoxicity criterion but with quite low probability for phycocyanobilin and phycoerythrobilin. The risk is higher for folic acid, with a probability reaching 0.80 , it is thus necessary to remain vigilant regarding this parameter. Phycocyanobilin and phycoerythrobilin may cause P-glycoprotein inhibition, a major actor in drug metabolism (Rautio et al. 2006). Such inhibition may enhance bioavailability of drugs by accumulation in cells which, if it is not the wanted effect, could lead to toxic effects. Thus, a particular attention should be paid regarding drug interactions with these two relevant compounds.

\section{Discussion}

In the global context of Covid-19 pandemic, joint advances in research are essential. Spike protein, a major structural protein of the SARS-CoV-2 constitutes a privileged target for antiviral research, as the first interactions between virus and human host cell take place via the Spike protein RBD, interacting with human ACE2 receptor.

Taking advantage of our skills with in silico studies, we choose to apply this knowledge as a test in the Covid-19 frame. Using largely widespread docking software, three Arthrospira molecules among 51 were identified as candidates for antiviral development. Folic acid, phycocyanobilin and phycoerythrobilin presented binding energy of respectively $-7.4,-7.2$ and -7.3 $\mathrm{kcal} . \mathrm{mol}^{-1}$. Regarding the complex Spike RBD / ACE2, with a binding energy of $-12.4 \mathrm{kcal}^{\mathrm{mol}}{ }^{-1}$, the three compounds could represent serious mid-competitive inhibitors, helping in the fight against Covid-19 pathology.

Phycocyanobilin and phycoerythrobilin are phycobilins of the respective phycobiliproteins C-phycocyanin and phycoerythrin. The tetrapyrrolic structure of these chromophores is involved in light harvesting of cyanobacteria such as Arthrospira (Akimoto 
et al. 2012; Rodrigues et al. 2018). Phycocyanin and phycoerythrin are authorized by both FDA and European Commission and are usually used as food coloring (Bratinova 2015).

No clinical trial on the website Clinicaltrials.com directly reported the use of those compounds with the aim to cure or prevent viral infections, thus opening a new way of research. Phycocyanins are mainly known for their great antioxidant properties (Zhou et al. 2005; Wu et al. 2016). In vitro study showed that phycocyanobilin represents the main Arthrospira compound responsible for its antioxidant effect (Hirata et al. 2000). Phycocyanobilin was shown to have a similar structure to a biliverdin, an NADPH inhibitor (Zheng et al. 2013). Phycocyanobilin is converted into phycocyanorubin by biliverdin reductase (Terry et al. 1993) with a structure close to bilirubin (McCarty 2007). In other in vivo studies, both phycocyanin and phycocyanobilin were able to normalize oxidative stress markers and expression of components from NADPH pathway (Zheng et al. 2013). Mc Carty (2010) suggested NADPH inhibition as a way of treatment in Influenza viral infection. Indeed, it has been identified as the main oxidative stress source in lung epithelial cells, participating in viral symptoms. Thus, phycocyanobilin and phycoerythrobilin present additional arguments to support their antiviral potential.

Folic acid, also known as vitamin B9 is a largely used molecule, approved and under health claims by both FDA and EFSA (FDA 2020; Barroso 2014). Folic acid is usually used during pregnancy to prevent the risk of neural tube defects (Greenberg et al. 2011). It is also widely used as concomitant treatment with Methotrexate to offset its side effects. Indeed Methotrexate (an antirheumatic drug) tends to exert a competitive activity against folic acid, necessitating a substantial supplementary administration of this folic acid (Shea et al. 2013). In this context, folic acid has been included in two clinical studies: one in HIV infected patients taking both Methotrexate and folic acid (Clinical trial $n^{\circ} \mathrm{NCT}$ 01949116) and a second one on hepatitis C infected patients (Clinical trial ${ }^{\circ}{ }^{\circ}$ CT02150291). This later studied how folic acid could act as prophylactic treatment in a viral infection to counteract side effects of the main treatment. These arguments are in favor of a safety and well-known consumption of folic acid which thus can be seriously considered as a candidate in the fight against Covid-19.

Toxicity parameters have been conducted in silico to check safety of these compounds. No carcinogenicity or mutagenicity was seen together with a safe high $\mathrm{LD}_{50}$, comprised between 500 and $5000 \mathrm{mg} \cdot \mathrm{kg}^{-1}$. No significant interaction with the main cytochromes and P-glycoprotein was predicted, suggesting no drug interaction. While a low hepatotoxicity risk has been detected, folic acid, phycocyanobilin and phycoerythrobilin remain known and authorized compounds, both in USA and Europe. These molecules also possess specific biological activities such as antioxidant which may further increase the relevance of their utilization as an antiviral treatment for Covid-19.

Except preprint publications, few papers refer to in silico research of Spike protein ligand. Sinha et al. (Sinha et al. 2020) studied interactions of saikosaponins, bioactive molecules from Traditional Chinese Medicine plants, with the entire Spike protein in open conformation. Their results highlighted three saikosaponins $(\mathrm{V}, \mathrm{U}, \mathrm{C})$, showing binding energies comprised between -7.2 and $-8.4 \mathrm{kcal}^{\mathrm{mol}}{ }^{-1}$. Excepting saikosaponin $\mathrm{V}$ which interacted with one key binding residue of the Spike protein/ACE2 link (475), none of the two others interacted with key binding residues involved in this critical bind. Another publication presented only hesperidin as potent inhibitor of Spike/ACE2 interface despite a quite large list of compounds with high binding energies (Wu et al. 2020).

On the basis of these results, our work provides a significant stone on this subject in view of the few results published to date. It will be more interesting to follow the future work that will deal with the interaction of our 3 molecules in viral episodes and further in silico studies will improve and guide bioactive molecule selection for antiviral compound research.

\section{Declarations}

\section{Competing interests:}

The authors declare no competing interests.

\section{References}

Page $10 / 21$ 
Abdo SM, Hetta MH, El-Senousy WM, El RAS, Ali GH (2012) Antiviral Activity of Freshwater Algae. J Appl Pharm Sci 2:21-25.

Akimoto S, Yokono M, Hamada F, Teshigahara A, Aikawa S, Kondo A (2012) Adaptation of light-harvesting systems of Arthrospira platensis to light conditions, probed by time-resolved fluorescence spectroscopy. Biochim Biophys Acta BBA Bioenerg 1817:1483-1489.

Ayehunie S, Belay A, Baba TW, Ruprecht RM (1998) Inhibition of HIV-1 Replication by an Aqueous Extract of Spirulina platensis(Arthrospira platensis). JAIDS J Acquir Immune Defic Syndr 18:7-12.

Azabji-Kenfack M, Dikosso SE, Loni EG, Onana EA, Sobngwi E, Gbaguidi E, Kana ALN, Nguefack-Tsague G, Von der Weid D, Njoya O, Ngogang J (2011) Potential of Spirulina Platensis as a Nutritional Supplement in Malnourished HIV-Infected Adults in Sub-Saharan Africa: A Randomised, Single-Blind Study. Nutr Metab Insights 4:29-37.

Barroso JM (2014) Commission regulation (EU) No 1135/2014 on the authorization of a health claim made on foods and referring to the reduction of disease risk. Official Journal of the European Union L307:23-24.

Belouzard S, Chu VC, Whittaker GR (2009) Activation of the SARS coronavirus spike protein via sequential proteolytic cleavage at two distinct sites. Proc Natl Acad Sci 106:5871-5876.

Böttcher E, Matrosovich T, Beyerle M, Klenk HD, Garten W, Matrosovich M (2006) Proteolytic Activation of Influenza Viruses by Serine Proteases TMPRSS2 and HAT from Human Airway Epithelium. J Virol 80:9896-9898.

Bratinova S (2015) Provision of scientific and technical support with respect to the classification of extracts/concentrates with colouring properties either as food colours (food additives falling under Regulation (EC) No 1333/2008) or colouring foods url: https://publications.jrc.ec.europa.eu/repository/bitstream/JRC96974/final\%20report_colouring\%20food.pdf searched on 15 june 2020

Chen Y-H, Chang G-K, Kuo S-M, Huang SY, Hu IC, Lo YL, Shih SR (2016) Well-tolerated Spirulina extract inhibits influenza virus replication and reduces virus-induced mortality. Sci Rep 6:24253.

Chirasuwan N, Chaiklahan R, Kittakoop P, Chanasattru W, Ruengjitchatchawalya M, Tanticharoen M, Bunnag B (2009) Anti HSV-1 activity of sulphoquinovosyl diacylglycerol isolated from Spirulina platensis. ScienceAsia 35:137-141.

Choi S-Y, Bertram S, Glowacka I, Park YW, Pöhlmann S (2009) Type II transmembrane serine proteases in cancer and viral infections. Trends Mol Med 15:303-312.

Dallakyan S, Olson AJ (2015) Small-molecule library screening by docking with PyRx. Methods Mol Biol Clifton NJ 1263:243250.

de la Jara A, Ruano-Rodriguez C, Polifrone M, Assunçao P, Brito-Casillas Y, Wägner AM, Serra-Majem L (2018) Impact of dietary Arthrospira (Spirulina) biomass consumption on human health: main health targets and systematic review. J Appl Phycol 30:2403-2423.

Deyab M, Mofeed J, El-Bilawy E, Ward F (2020) Antiviral activity of five filamentous cyanobacteria against coxsackievirus B3 and rotavirus. Arch Microbiol 202:213-223.

Donoghue M, Hsieh F, Baronas E, Godbout K, Gosselin M, Stagliano N, Donovan M, Woolf B, Robinson K, Jeyaseelan R, Breitbart RE (2000) A Novel Angiotensin-Converting Enzyme-Related Carboxypeptidase (ACE2) Converts Angiotensin I to Angiotensin 1-9. Circ Res 87:1-9.

El-Baz FK, El-Senousy WM, El-Sayed AB, Kamel MM (2013) In vitro antiviral and antimicrobial activities of Spirulina platensis extract. J Appl Pharm Sci 3:052-056.

Page $11 / 21$ 
FDA (2020) Electronic code of federal regulations Subpart D - Special Dietary and Nutritional Additives.

https://clinicaltrials.gov/ct2/show/NCT01949116 searched on 10 june 2020.

Forli S, Huey R, Pique ME, Sanner MF, Goodsell DS, Olson AJ (2016) Computational protein-ligand docking and virtual drug screening with the AutoDock suite. Nat Protoc 11:905-919.

Gomaa M, El-Sheekh MM, El-Shafey AS, Metwally MA, El-Shanshory M, Eid MAW (2017) Immunological Studies in Egyptian Thalassemic Children Infected with Hepatitis C Virus. Am J Microbiol Biotechnol 4:20-26.

Greenberg JA, Bell SJ, Guan Y, Yu Y (2011) Folic Acid Supplementation and Pregnancy: More Than Just Neural Tube Defect Prevention. Rev Obstet Gynecol 4:52-59.

Gui M, Song W, Zhou H, Xu J, Chen S, Xiang Y, Wang X (2017) Cryo-electron microscopy structures of the SARS-CoV spike glycoprotein reveal a prerequisite conformational state for receptor binding. Cell Res 27:119-129.

Hamming I, Timens W, Bulthuis MLC, Lely AT, Navis GJ, Goor HV (2004) Tissue distribution of ACE2 protein, the functional receptor for SARS coronavirus. A first step in understanding SARS pathogenesis. J Pathol 203:631-637.

Hernández-Corona A, Nieves I, Meckes M, Chamorro G, Barron B (2002) Antiviral activity of Spirulina maxima against herpes simplex virus type 2. Antiviral Res 56:279-285.

Hetta M, Mahmoud R, El-Senousy W, Ibrahim M, El-Taweel G, Ali G (2014) Antiviral and antimicrobial activities of Spirulina platensis. World J Pharm Pharm Sci 3:31-39.

Hirata T, Tanaka M, Ooike M, Tsunomura T, Sakaguchi M (2000) Antioxidant activities of phycocyanobilin prepared from Spirulina platensis. J Appl Phycol 12:435-439.

Hoffmann M, Kleine-Weber H, Schroeder S, Krüger N, Herrler T, Erichsen S, Schiergens TS, Herrler G, Wu NH, Nitsche A, Müller MA, Drosten C, Pöhlmann S (2020) SARS-CoV-2 Cell Entry Depends on ACE2 and TMPRSS2 and Is Blocked by a Clinically Proven Protease Inhibitor. Cell 181:271-280.

Hsue P and Currier J (2018) Clinicaltrials. Safety and effectiveness of low-dose Methotrexate for reducing inflammation in HIVinfected adults on ARV medications. https://clinicaltrials.gov/ct2/show/NCT01949116 searched on 15 june 2020.

Jang I-S, Park SJ (2016) A Spirulina maxima-derived peptide inhibits HIV-1 infection in a human T cell line MT4. Fish Aquat Sci 19:37.

Kok Y-Y, Chu W-L, Phang S-M, Mohamed SM, Naidu R, Lai PJ, Ling SN, Mak JW, Lim PKC, Balraj P, Khoo ASB (2011) Inhibitory activities of microalgal extracts against Epstein-Barr virus DNA release from lymphoblastoid cells. J Zhejiang Univ Sci B $12: 335-345$.

Lan J, Ge J, Yu J, Shan S, Zhou H, Fan S, Zhang Q, Shi X, Wang Q, Zhang L, Wang X (2020) Structure of the SARS-CoV-2 spike receptor-binding domain bound to the ACE2 receptor. Nature 581:215-220.

Lee J-B, Hou X, Hayashi K, Hayashi T (2007) Effect of partial desulfation and oversulfation of sodium spirulan on the potency of anti-herpetic activities. Carbohydr Polym 69:651-658.

Li F (2016) Structure, Function, and Evolution of Coronavirus Spike Proteins. Annu Rev Virol 3:237-261.

Li F, Li W, Farzan M, Harrison SC (2005) Structure of SARS Coronavirus Spike Receptor-Binding Domain Complexed with Receptor. Science 309:1864-1868.

Madu IG, Roth SL, Belouzard S, Whittaker GR (2009) Characterization of a Highly Conserved Domain within the Severe Acute Respiratory Syndrome Coronavirus Spike Protein S2 Domain with Characteristics of a Viral Fusion Peptide. J Virol 83:7411-

Page $12 / 21$ 
7421.

McCarty MF (2007) Clinical potential of Spirulina as a source of phycocyanobilin. J Med Food 10:566-570.

McCarty MF, Barroso-Aranda J, Contreras F (2010) Practical strategies for targeting NF-kappaB and NADPH oxidase may improve survival during lethal influenza epidemics. Med Hypotheses 74:18-20.

Millet JK, Séron K, Labitt RN, Danneels A, Palmer KE, Whittaker GR, Dubuissn J, Belouzard S (2016) Middle East respiratory syndrome coronavirus infection is inhibited by griffithsin. Antiviral Res 133:1-8.

Mimouni V, Ulmann L, Pasquet V, Mathieu M, Picot L, Bougaran G, Cadoret JP, Morant-Manceau A, Schoefs B (2012) The Potential of Microalgae for the Production of Bioactive Molecules of Pharmaceutical Interest. Curr Pharm Biotechnol 13:27332750.

Nermeen NA (2014) Clinicaltrials. A pilot study to assess the efficacy and safety of folic acid and/or vitamin B complex on Hepatitis $C$ infected patients treated with pegylated interferon and ribavirin.

https://clinicaltrials.gov/ct2/show/NCT02150291?term=folic+acid\&cond=Virus\&draw=2\&rank=6 searched on 15 june 2020.

Ngo-Matip M-E, Pieme CA, Azabji-Kenfack M, Moukette BM, Korosky E, Stefanini P, Ngogang JY, Mbofung CM (2015) Impact of daily supplementation of Spirulina platensis on the immune system of naïve HIV-1 patients in Cameroon: a 12-months single blind, randomized, multicenter trial. Nutr J 14:70.

Nguyen NT, Nguyen TH, Pham TNH, Huy NT, Bay MV, Pham MQ, Nam PC, Vu VV, Ngo ST (2020) Autodock Vina Adopts More Accurate Binding Poses but Autodock4 Forms Better Binding Affinity. J Chem Inf Model 60:204-211.

O’Boyle NM, Banck M, James CA, Morley C, Vandermeersch T, Hutchison GR (2011) Open Babel: An open chemical toolbox. J Cheminformatics 3:33.

Ortega JT, Serrano ML, Pujol FH, Rangel HR (2020) Role of changes in SARS-CoV-2 spike protein in the interaction with the human ACE2 receptor: An in silico analysis. EXCLI J 19:410-417. doi:https://doi.org/10.17179/excli2020-1167

Ou X, Liu Y, Lei X, Li P, Mi D, Ren L, Guo L, Guo R, Chen T, Hu J, Xiang Z, Mu Z, Chen X, Chen J, Hu K, Jin Q, Wang J, Qian Z (2020) Characterization of spike glycoprotein of SARS-CoV-2 on virus entry and its immune cross-reactivity with SARS-CoV. Nat Commun 11:1620.

Pendyala B, Patras A (2020) In silico screening of food bioactive compounds to predict potential inhibitors of Covid-19 main protease (Mpro) and RNA-dependent RNA polymerase (RdRp). ChemRxiv

url:https://chemrxiv.org/articles/In_silico_Screening_of_Food_Bioactive_Compounds_to_Predict_Potential_Inhibitors_of_COVID19_Main_protease_Mpro_and_RNA-dependent_RNA_polymerase_RdRp_/12051927/2

Perumal E, Sundararaj R (2020) Algae: A Potential Source to Prevent and Cure the Novel Coronavirus - A review. Int J Emerg Technol 11:479-483

Radonic A, Thulke S, Achenbach J, Kurth A, Vreemann A(2010) Anionic Polysaccharides From Phototrophic Microorganisms Exhibit Antiviral Activities to Vaccinia Virus. J Antivir Antiretrovir 02: 051-055.

Rautio J, Humphreys JE, Webster LO, Balakrishnan A, Keogh JP, Kunta JR, Serabjit-Singh C, Polli JW (2006) In Vitro PGlycoprotein Inhibition Assays for Assessment of Clinical Drug Interaction Potential of New Drug Candidates: A Recommendation for Probe Substrates. Drug Metab Dispos 34:786-792.

Rechter S, König T, Auerochs S, thulke S, Walter H, Dörnenburg H, Walter C, Marschall M (2006) Antiviral activity of Arthrospiraderived spirulan-like substances. Antiviral Res 72:197-206.

Page $13 / 21$ 
Rodrigues RDP, de Castro FC, Santiago-Aguiar RS de, Rocha MVP (2018) Ultrasound-assisted extraction of phycobiliproteins from Spirulina (Arthrospira) platensis using protic ionic liquids as solvent. Algal Res 31:454-462.

Schnitzler P, Sharaf M, Amara A, Aboul-Enein A, Helmi S, Ballot A (2013) Antiherpetic efficacy of aqueous extracts of the cyanobacterium Arthrospira fusiformis from Chad. Pharmazie 68:376-380.

Shalaby EA, Shanab S, Singh V (2010) Salt stress enhancement of antioxidant and antiviral efficiency of Spirulina platensis. J Med Plants Res 4:2622-2632.

Shang J, Ye G, Shi K, Wan Y, Luo C, Aihara H, Geng Q, Auerbach A, Li F (2020) Structural basis of receptor recognition by SARSCoV-2. Nature 581:221-224.

Shea B, Swinden MV, Ghogomu ET, Ortiz Z, Katchamart W, Rader T, Bombardier C, Wells GA, Tugwell P (2013) Folic acid and folinic acid for reducing side effects in patients receiving methotrexate for rheumatoid arthritis. Cochrane Database Syst Rev 5.

Shulla A, Heald-Sargent T, Subramanya G, Zhao J, Perlman S, Gallagher T (2011) A Transmembrane Serine Protease Is Linked to the Severe Acute Respiratory Syndrome Coronavirus Receptor and Activates Virus Entry. J Virol 85:873-882.

Sinha SK, Shakya A, Prasad SK, Singh S, Gurav NS, Prasad RS, Gurav SS (2020) An in-silico evaluation of different Saikosaponins for their potency against SARS-CoV-2 using NSP15 and fusion spike glycoprotein as targets. J Biomol Struct Dyn 1-12.

Subhash GV, Kumar GRK, Sapre A, Dasgupta S (2020) Possible prevention of Covid-19 by using linoleic acid (C18) rich algae oil. 36. url:https://preprints.aijr.org/index.php/ap/preprint/view/36/15

Talukdar J, Dasgupta S, Nagle V, Bhadra B (2020) COVID-19: Potential of Microalgae Derived Natural Astaxanthin As Adjunctive Supplement in Alleviating Cytokine Storm. SSRN Electron J. doi:10.31219/osf.io/yahd4

Teas J, Irhimeh MR (2012) Dietary algae and HIV/AIDS: proof of concept clinical data. J Appl Phycol 24:575-582.

Terry MJ, Maines MD, Lagarias JC (1993) Inactivation of phytochrome- and phycobiliprotein-chromophore precursors by rat liver biliverdin reductase. J Biol Chem 268:26099-26106.

Trott O, Olson AJ (2010) AutoDock Vina: Improving the speed and accuracy of docking with a new scoring function, efficient optimization, and multithreading. J Comput Chem 31:455-461.

Vangone A, Bonvin AM (2015) Contacts-based prediction of binding affinity in protein-protein complexes. eLife 4:1-15.

Walls AC, Park Y-J, Tortorici MA, Wall A, McGuire A, Veesler D (2020) Structure, Function, and Antigenicity of the SARS-CoV-2 Spike Glycoprotein. Cell 181:281-292.

Walls AC, Tortorici MA, Snijder J, Xiong X, Bosch BJ, Rey FA, Veesler D (2017) Tectonic conformational changes of a coronavirus spike glycoprotein promote membrane fusion. Proc Natl Acad Sci 114:11157-11162.

Wang Q, Zhang Y, Wu L, Niu S, Song C, Zhang Z, Lu G, Qiao C, Hu Y, Yuen KY, Wang Q, Zhou H, Yan J, Qi J (2020) Structural and Functional Basis of SARS-CoV-2 Entry by Using Human ACE2. Cell 181:894-904.

Winter FS, Emakam F, Kfutwah A, Hermann J, Azabji-Kenfack M, Krawinkel M (2014) The Effect of Arthrospira platensis Capsules on CD4 T-Cells and Antioxidative Capacity in a Randomized Pilot Study of Adult Women Infected with Human Immunodeficiency Virus Not under HAART in Yaoundé, Cameroon. Nutrients 6:2973-2986.

Wrapp D, Wang N, Corbett KS, Goldsmith JA, Hsieh CL, Abiona O, Graham BS, McLellan JS (2020) Cryo-EM structure of the 2019-nCoV spike in the prefusion conformation. Science 367:1260-1263. 
Wu C, Liu Y, Yang Y, Zhang P, Zhong W, Wang Y, Wang Q, Xu Y, Li M, Li X, Zheng M, Chen L, Li H (2020) Analysis of therapeutic targets for SARS-CoV-2 and discovery of potential drugs by computational methods. Acta Pharm Sin B.

Xue LC, Rodrigues JP, Kastritis PL, Bonvin AM, Vangone A (2016) PRODIGY: a web server for predicting the binding affinity of protein-protein complexes. Bioinformatics 32:3676-3678.

Yakoot M, Salem A (2012) Spirulina platensis versus Silymarin in the treatment of chronic hepatitis C virus infection. A pilot randomized, comparative clinical trial. BMC Gastroenterol 12:32.

Yan R, Zhang Y, Li Y, Xia L, Guo Y, Zhou Q (2020) Structural basis for the recognition of SARS-CoV-2 by full-length human ACE2. Science 367:1444-1448.

Yang H, Lou C, Sun L, Li J, Cai Y, Wang Z, Li W, Liu G, Tang Y (2019) admetSAR 2.0: web-service for prediction and optimization of chemical ADMET properties. Bioinformatics 35:1067-1069.

Yuan Y, Cao D, Zhang Y, Cao D, hang Y, Ma J, Qi J, Wang Q, Lu G, Wu Y, Yan J, Shi Y, Zhang X, Gao GF (2017) Cryo-EM structures of MERS-CoV and SARS-CoV spike glycoproteins reveal the dynamic receptor binding domains. Nat Commun 8:15092.

Zheng J, Inoguchi T, Sasaki S, Maeda Y, McCarty MF, Fujii M, Ikeda N, Kobayashi K, Sonoda N, Takayanagi R (2013) Phycocyanin and phycocyanobilin from Spirulina platensis protect against diabetic nephropathy by inhibiting oxidative stress. Am J Physiol Regul Integr Comp Physiol 304:R110-120.

\section{Tables}

Table 1 Binding residues involved in Spike RBD / ACE2 link; green residues correspond to consensus sequences

\begin{tabular}{|l|c|}
\hline \multicolumn{1}{|c|}{ ACE2 } & References \\
\hline S19, Q24, K31, E35, D38, L79, M82, Y83, K353. & Shang et al., 2020 \\
\hline Q24, D30, H34, Y41, Q42, M82, K353, R357. & Yan et al., 2020 \\
\hline S19, Q24, F28, D30, K31, H34, D38, Y41, Q42, L79, M82, Y83, K353, D355. & Wang et al., 2020 \\
\hline Q24, T27, F28, D30, K31, H34, E35, E37, D38, Y41, Q42, L79, M82, Y83, N330, K353, G354, D355, R357, R393. & Lan et al., 2020 \\
\hline \multicolumn{1}{|c|}{ SPIKE RBD } & References \\
\hline L455, F486, Q493, S494, N501. & Shang et al., 2020 \\
\hline K417, Y453, Q474, F486, Q498, T500, N501. & Yan et al., 2020 \\
\hline K417, G446, Y449, Y453, A475, E484, F486, N487, Y489, G496, Q498, T500, G502. & Wang et al., 2020 \\
\hline $\begin{array}{l}\text { T402, Y436, N439, } \\
\text { Y440, L455, N473, F486, G488, Y491, Q493, Q498, N501. }\end{array}$ & Walls et al., 2020 \\
\hline K417, G446, Y449, Y453, L455, F456, A475, F486, N487, Y489, Q493, G496, Q498, T500, N501, G502, Y505. & Lan et al., 2020 \\
\hline
\end{tabular}

Table 2 In vitro evaluation of Arthrospira antiviral activity: state of the art 


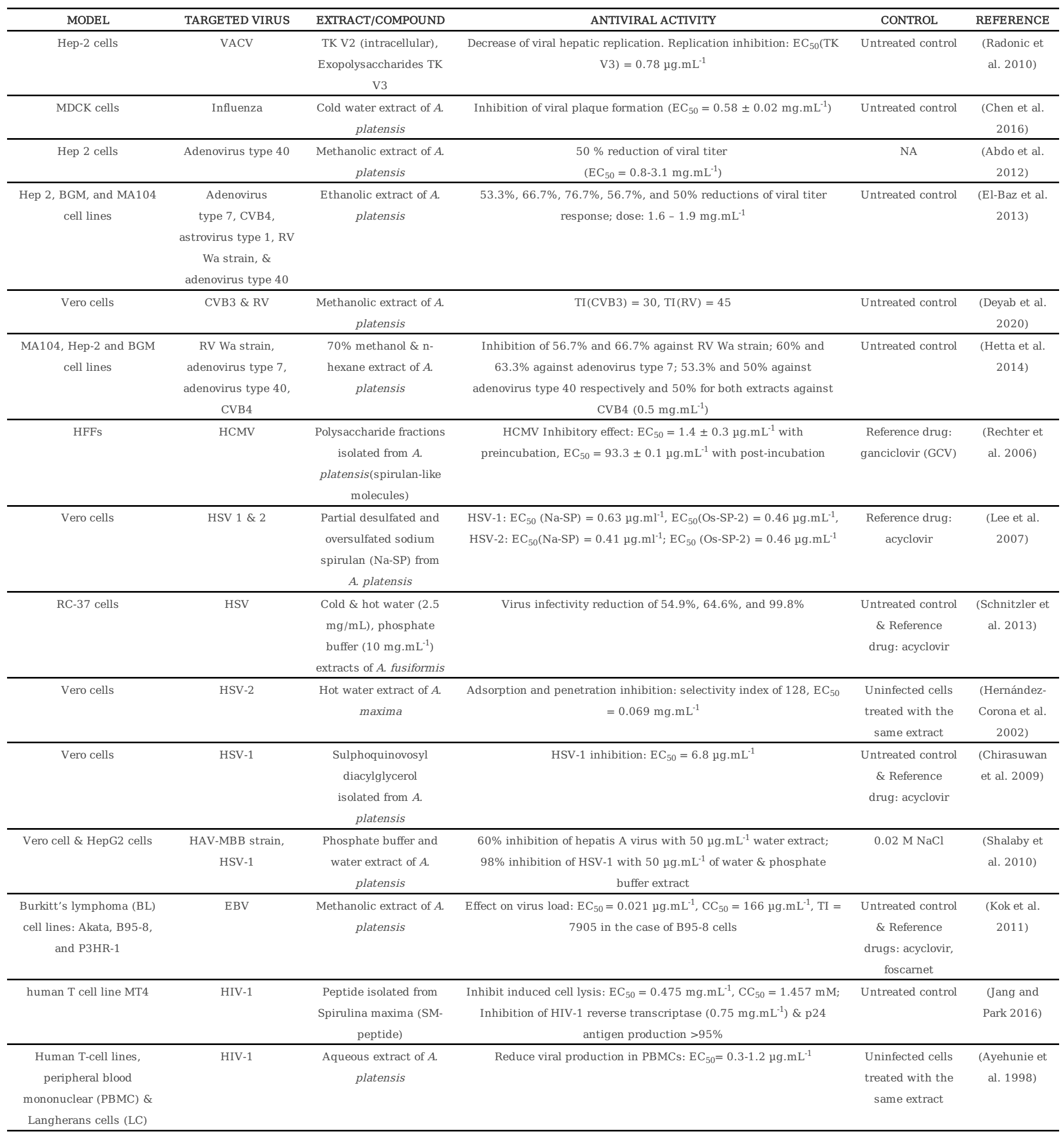

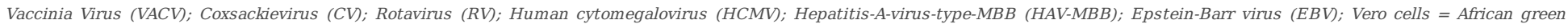
monkey kidney; Human Immunodeficiency virus (HIV); NA : Not Available

Table 3 Clinical study evaluation of Arthrospira antiviral activity: state of the art 


\begin{tabular}{|c|c|c|c|c|c|c|c|}
\hline MODEL & $\begin{array}{c}\text { TARGETED } \\
\text { VIRUS }\end{array}$ & $\begin{array}{l}\text { EXTRACT/ } \\
\text { COMPOUND }\end{array}$ & ANTIVIRAL ACTIVITY & BENEFICIAL EFFECT & DURATION & $\begin{array}{c}\text { STUDY } \\
\text { PARAMETERS }\end{array}$ & REFERENCE \\
\hline $\begin{array}{c}73 \text { HIV- } \\
\text { infected } \\
\text { adult females }\end{array}$ & HIV & $\begin{array}{l}5 \text { g.day }^{-1} \text { of } \\
\text { A. platensis }\end{array}$ & No effect on the viral load and/or the CD4 T-cells & $\begin{array}{c}\text { Improvement of anemia status, } \\
\text { good nutritional rehabilitation } \\
\text { effects }\end{array}$ & 3 months & $\begin{array}{l}\text { Placebo, } \\
\text { randomized, } \\
\text { double-blind }\end{array}$ & $\begin{array}{c}\text { (Winter et al. } \\
\text { 2014) }\end{array}$ \\
\hline $\begin{array}{l}11 \\
\text { antiretroviral- } \\
\text { naïve }\end{array}$ & HIV-1 & $\begin{array}{l}5 \text { g.day }^{-1} \text { of } \\
\text { dried } A \text {. } \\
\text { platensis }\end{array}$ & $\begin{array}{c}\text { No significant effect on } \mathrm{CBC} \text {, metabolic \& lipid } \\
\text { panel; stable CD4 \& virus load }\end{array}$ & $\begin{array}{l}\text { Clinically significant improvement } \\
\left.\text { in CD4 (>100 cells. } \mathrm{mL}^{-1}\right) \\
\text { decreased HIV viral load of } 0.5 \\
\quad \log 10 \text { for } 1 \text { subject }\end{array}$ & 3 months & $\begin{array}{c}\text { Placebo, } \\
\text { randomized }\end{array}$ & $\begin{array}{l}\text { (Teas and } \\
\text { Irhimeh } \\
\text { 2012) }\end{array}$ \\
\hline $\begin{array}{c}320 \text { naïve } \\
\text { HIV-1 } \\
\text { patients }\end{array}$ & HIV-1 & $\begin{array}{l}10 \text { g.day }^{-1} \text { of } \\
\text { dried } A \text {. } \\
\text { platensis }\end{array}$ & $\begin{array}{l}\text { Significant increase of CD4 count cells, decrease of } \\
\text { viral load level \& higher hemoglobin level }\end{array}$ & $\begin{array}{l}\text { Improve immune system \& prevent } \\
\text { opportunistic diseases }\end{array}$ & 12 months & $\begin{array}{c}\text { Randomized, } \\
\text { single-blind, } \\
\text { control without } \\
\text { spirulina } \\
\end{array}$ & $\begin{array}{l}\text { (Ngo-Matip } \\
\text { et al. 2015) }\end{array}$ \\
\hline $\begin{array}{l}52 \text { HIV- } \\
\text { infected }\end{array}$ & HIV-1 & $\begin{array}{l}0.2 \text { to } 0.37 \\
\text { g. } \mathrm{kg}^{-1} \cdot \mathrm{day}^{-1} \\
\text { of } A \text {. } \\
\text { platensis }\end{array}$ & $\begin{array}{l}\text { Significantly lower viral load, higher CD } 4 \text { count, } \\
\text { increase in hemoglobin level }\left(1.6 \mathrm{~g} \cdot \mathrm{dL}^{-1}\right)\end{array}$ & Increase quality of weight gain & 3 months & $\begin{array}{l}\text { Randomized, } \\
\text { single-blind, } \\
\text { control group }\end{array}$ & $\begin{array}{l}\text { (Azabji- } \\
\text { Kenfack et al. } \\
\text { 2011) }\end{array}$ \\
\hline $\begin{array}{l}25 \\
\text { thalassemic } \\
\text { children } \\
\text { HCV-infected }\end{array}$ & $\mathrm{HCV}$ & $\begin{array}{l}250 \mathrm{mg} \cdot \mathrm{kg}^{-} \\
{ }^{1} \text {.day }^{-1} \text { of } A \text {. } \\
\text { platensis }\end{array}$ & $\begin{array}{c}\text { Significant increase of CD4 (from } 19.56 \pm 7.8 \text { to } \\
32.2 \pm 13.5 \times 10^{3} \text { cells } .100 \mathrm{~mL}^{-1} \text { ) \& CD8 (from } \\
17.68 \pm 6.88 \text { to } 26.44 \pm 9.08 \times 10^{3} \text { cells. } 100 \mathrm{~mL}^{-1} \text { ) } \\
\text { after } 6 \text { months }\end{array}$ & Immune stimulation & 6 months & NA & $\begin{array}{c}\text { (Gomaa et al. } \\
\text { 2017) }\end{array}$ \\
\hline $\begin{array}{l}66 \mathrm{HCV}- \\
\text { infected }\end{array}$ & $\mathrm{HCV}$ & $\begin{array}{l}3 \mathrm{x} 500 \\
\mathrm{mg} \cdot \text { day }^{-1} \text { of } \\
\text { A. platensis }\end{array}$ & $\begin{array}{l}\text { No significant effect on virus load; ALT, CLDG \& } \\
\text { ASEX improved by spirulina }\end{array}$ & $\begin{array}{c}\text { Loss or reduction of detectable } \\
\text { hepatitis C virus RNA for } 6 \\
\text { patients }\end{array}$ & 6 months & $\begin{array}{l}\text { Randomized, } \\
\text { double-blind, } \\
\text { control group } \\
\text { (3x } 140 \text { g of } \\
\text { Silymarin/day) }\end{array}$ & $\begin{array}{l}\text { (Yakoot and } \\
\text { Salem 2012) }\end{array}$ \\
\hline
\end{tabular}

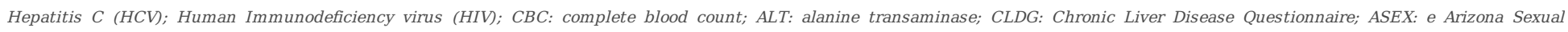
Experiences Scale; NA: Not Available

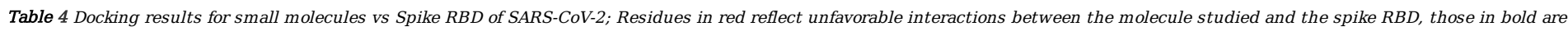
directly involved in the link between ACE2 and spike RBD. Stars were added to amino acids involved in H-bond

\begin{tabular}{|c|c|c|c|c|c|}
\hline Molecules & $\begin{array}{l}\text { Pubchem } \\
\text { ID }\end{array}$ & $\begin{array}{l}\text { Binding affinity (kcal.mol }{ }^{-} \\
\left.{ }^{1}\right)\end{array}$ & RMSD/ub & $\mathrm{RMSD} / \mathrm{lb}$ & Binding residues \\
\hline Catechin & 9064 & -7.2 & 0 & 0 & ARG403, GLU406*, TYR453, GLY496, ASN501*, TYR505 \\
\hline Epicatechin & 72276 & -7.1 & 0 & 0 & ARG403*, TYR453, GLY496*,TYR505 \\
\hline Dieckol & 3008868 & -8.5 & 0 & 0 & ARG403, GLU406, ARG408,LYS417, TYR449, TYR453, GLN498* \\
\hline Apigenin & 5280443 & -7.1 & 0 & 0 & ARG403*, TYR453, GLY496,TYR505* \\
\hline Beta-carotene & 5280489 & -7.1 & 0 & 0 & TYR449, LEU452, PHE490, TYR505 \\
\hline Rutin & 5280805 & -7.4 & 0 & 0 & GLN493*, GLY496, ASN501*,TYR505* \\
\hline Astaxanthin & 5281224 & -7.1 & 0 & 0 & TYR449, LEU452, TYR505 \\
\hline Rosmarinic acid & 5281792 & -7.1 & 0 & 0 & ARG403*, TYR449,GLN493*, PHE497, TYR505* \\
\hline \multirow[t]{2}{*}{ Phycobilin } & \multirow[t]{2}{*}{6438349} & -7.2 & 0 & 0 & ARG403*, TYR449, SER494*, TYR495, GLY496*, PHE497,GLN498*, TYR505 \\
\hline & & -7.2 & 1.997 & 1.607 & TYR449*, SER494*, TYR495, GLY496*, PHE497, GLN498*, TYR505 \\
\hline Phycoerythrobilin & 6443764 & -7.3 & 0 & 0 & ARG403, LYS417, TYR449,TYR453, SER494*, GLY496* \\
\hline \multirow[t]{2}{*}{ Folic acid } & \multirow[t]{2}{*}{135398658} & -7.4 & 0 & 0 & $\begin{array}{c}\text { ARG403, ASP405*, GLU406*, ARG408, GLN409*, TYR453, TYR495, GLY496*, GLN498*, } \\
\text { ASN501* }\end{array}$ \\
\hline & & -7.3 & 1.921 & 1.536 & ARG403, ASP405*, GLU406*, LYS417, TYR453, SER494, TYR495, TYR505* \\
\hline
\end{tabular}

Table 5 Toxicity parameters of phycocyanobilin, phycoerythrobilin and folic acid. Orange data highlights positive results with a probability $>0.70$ 


\begin{tabular}{|l|c|c|c|c|c|c|}
\hline \multirow{2}{*}{} & \multicolumn{2}{|c|}{ Phycocyanobilin } & \multicolumn{2}{c|}{ Phycoerythrobilin } & \multicolumn{2}{c|}{ Folic acid } \\
\cline { 2 - 8 } & Value & Probability & Value & Probability & Value & Probability \\
\hline Ames mutagenesis & - & 0.71 & - & 0.67 & - & 0.80 \\
\hline Acute Oral Toxicity (c) & III & 0.59 & III & 0.58 & III & 0.62 \\
\hline Carcinogenicity (binary) & - & 0.87 & - & 0.90 & - & 0.87 \\
\hline CYP1A2 inhibition & + & 0.52 & - & 0.58 & - & 0.93 \\
\hline CYP2C19 inhibition & - & 0.73 & - & 0.78 & - & 0.92 \\
\hline CYP2C9 inhibition & + & 0.52 & - & 0.53 & - & 0.91 \\
\hline CYP2D6 inhibition & - & 0.87 & - & 0.88 & - & 0.94 \\
\hline CYP3A4 inhibition & - & 0.74 & - & 0.78 & - & 0.91 \\
\hline Hepatotoxicity & + & 0.67 & + & 0.57 & + & 0.80 \\
\hline P-glycoprotein inhibition & + & 0.77 & + & 0.78 & - & 0.87 \\
\hline
\end{tabular}

Figures

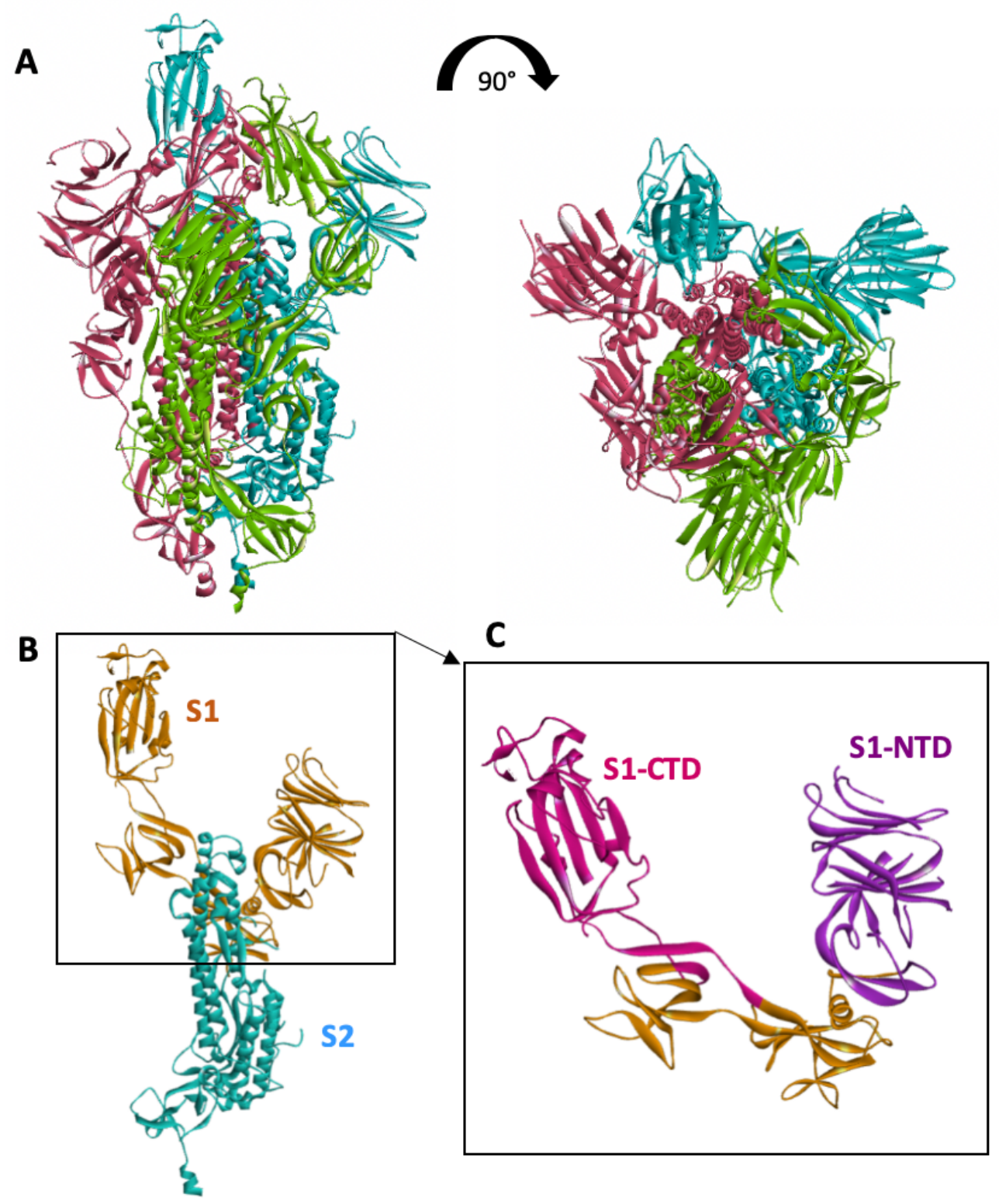

Figure 1 
A. Cryo-electron microscopy structure of prefusion trimeric SARS-CoV-2 spike protein (from PDB: 6LZG). Three monomers are identified (pink, green and blue) from two angles of view. B. Monomer structure of SARS-CoV-2 spike protein, subunit S1 is represented in orange and S2 in blue. C. RBD localization in S1 subunit: S1 C-terminal domain (S1-CTD = RBD) appears in pink and S1 N-terminal domain (S1-NTD) in purple

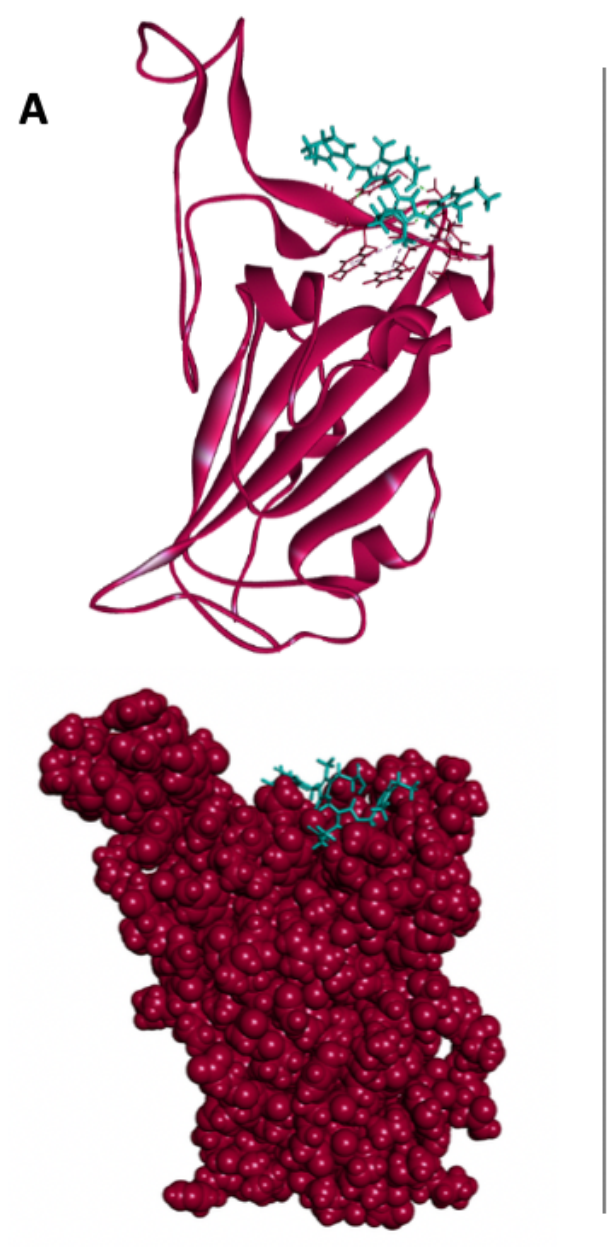

B

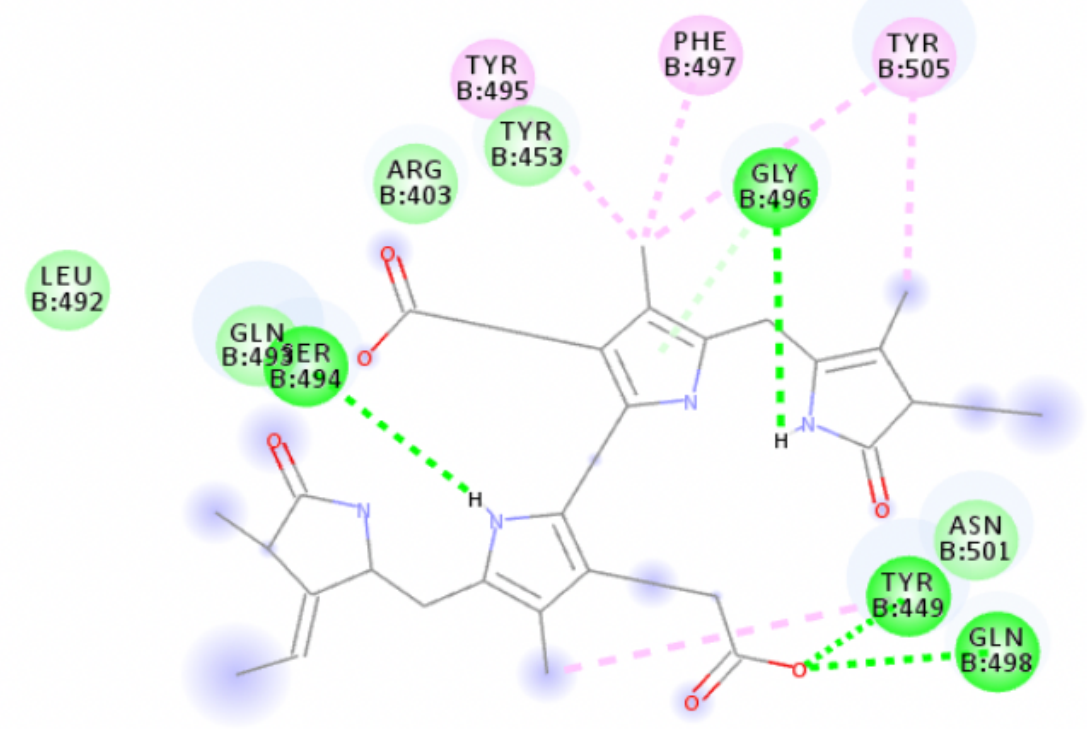

Interactions

van der Waals

Conventional Hydrogen Bond

Pi-Donor Hydrogen Bond

Pi-Alkyl

\section{Figure 2}

Phycobilin docked with spike RBD of SARS-CoV-2. A. 3D structure of the complex, phycobilin (ligand) is represented in green, Spike RBD (receptor) is in dark pink B. Interaction map of the ligand/receptor complex 
A

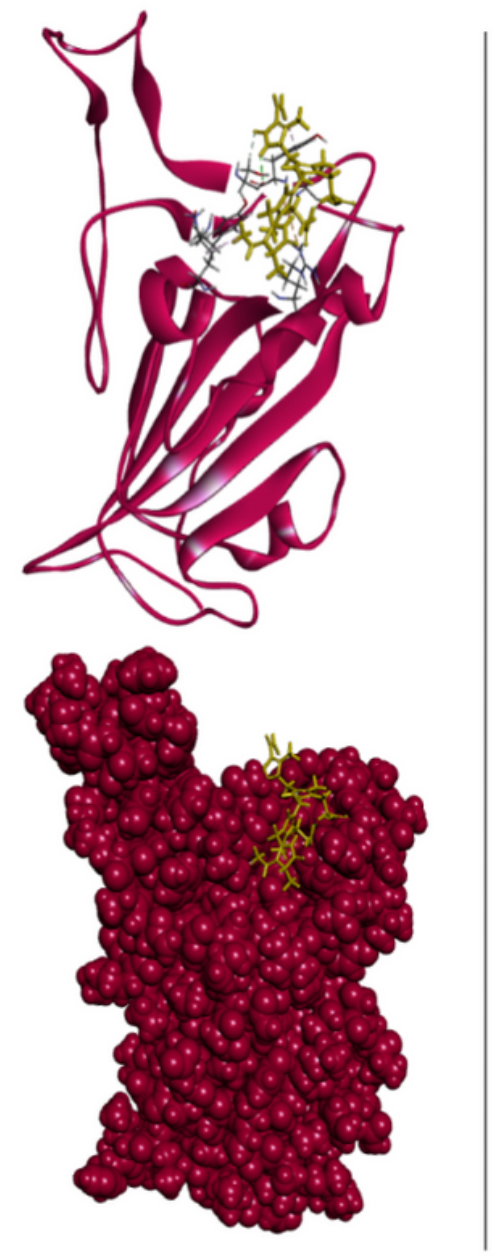

B

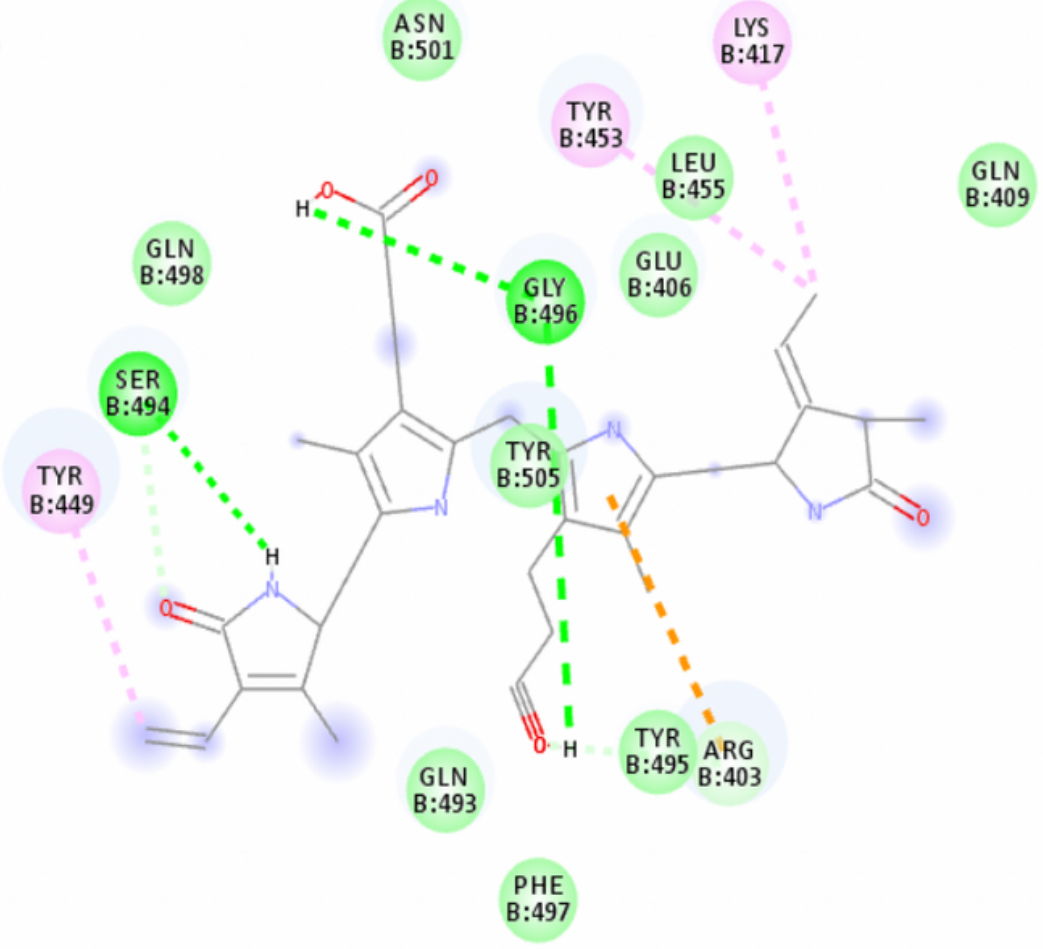

Interactions

van der Waals

Conventional Hydrogen Bond

Carbon Hydrogen Bond

\section{Figure 3}

Phycoerythrobilin docked with spike RBD of SARS-CoV-2. A. 3D structure of the complex, phycoerythrobilin (ligand) is represented in green, Spike RBD (receptor) is in dark pink B. Interaction map of the ligand/receptor complex 
A

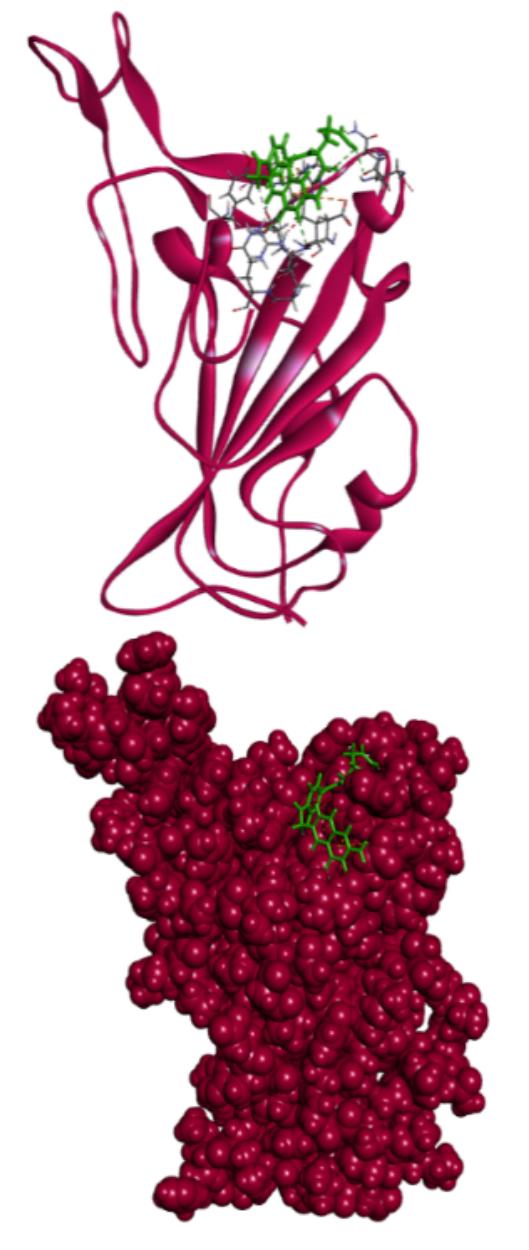

B

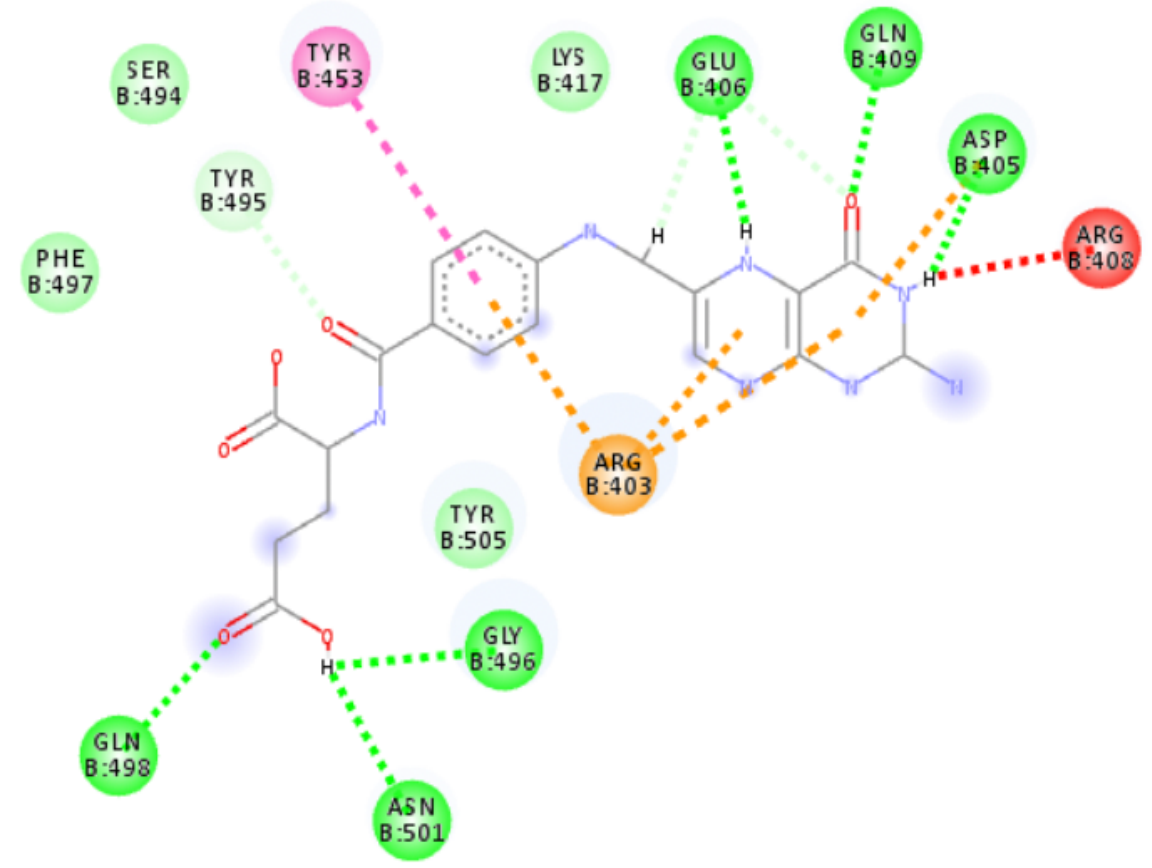

\section{Interactions}

van der Waals

Conventional Hydrogen Bond

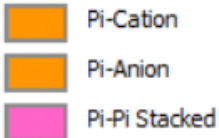

Carbon Hydrogen Bond

Unfavorable Donor-Donor

Figure 4

Folic acid docked with spike RBD of SARS-CoV-2. A. 3D structure of the complex, folic acid (ligand) is represented in green, Spike RBD (receptor) is in dark pink B. Interaction map of the ligand/receptor complex

\section{Supplementary Files}

This is a list of supplementary files associated with this preprint. Click to download.

- SupplementarydataTable6.docx 